\title{
Surgical Hepatosplenic Mansonic Schistosomiasis in Adolescents: Repercussions of the Post-treatment Schistosomotic Burden on the Hepatic Functional Reserve
}

\author{
Carlos Teixeira Brandt ${ }^{+}$, Maria Vírginia da Mota Braga, Karina Leal Melo, \\ Helena Pinho Sá, Rodrigo Carvalheira
}

\author{
Hospital das Clínicas, Departamento de Cirurgia, CCS, UFPE, Av. Moraes Rego s/noํ, 50670-420 \\ Recife, PE, Brasil
}

Schistosomiasis mansoni affects the hepatic functional reserve. Clinical treatment with oxamniquine is not $100 \%$ effective and there has been found strain of this parasite resistant to this drug. The aims of this investigation were: (1) to examine the presence of residual parasite burden after medical and surgical treatment on adolescents with surgical schistosomiasis mansoni and (2) to assess the effect on the hepatic functional reserve in patients with and without residual infection. Twenty nine children with hepatosplenic schistosomiasis mansoni and bleeding esophageal varices were treated with oxamniquine. They underwent splenectomy, ligature of the left gastric vein and autologous implantation of spleen tissue into the greater omentum. After a mean post-operative follow up of five years they underwent rectal biopsy for schistosomotic egg search. They were divided in patients with and without infection. In 20 patients the submucosal egg search was negative, however, in 9 it was positive. The hepatic functional reserve in the patients without infection was as follows: 17 were Child-Pugh $A$ and 3 Child-Pugh B. In the patients who were still infected 6 were Child-Pugh A and 3 Child-Pugh B. The $\chi^{2}$ analysis of the hepatic functional reserve showed $\chi^{2}=3.19-p=0.07$. From the results the following conclusion can be drawn: residual infection or reinfection in the follow up period had not interfered with the distribution of the hepatic functional reserve of the patients in this series. However, there was a trend for a decrease of this parameter in patients with residual infection.

Key words: mansonic schistosomiasis - schistosomotic egg burden - hepatic functional reserve

Schistosomiasis mansoni is an endemic disease in Northeastern, Brazil. In Pernambuco, this condition is the third mortality cause among the so-called rural endemic diseases. In this way it represents an important problem of public health (Amaral et al. 1994, Barbosa et al. 1996, 1997).

The patients who suffer from schistosomiasis mansoni in its hepatosplenic form represent about $2 \%$ to $7 \%$ of the infected northeastern Brazilian population (Barreto \& Domingues 1996). About 100,000 of these patients present with recurrent upper digestive bleeding and may require medical and surgical treatments. Oxamniquine and praziquantel are the main drugs for this parasite (Cunha 1982, 1986, 1997, Cunha \& Ferrari 1991).

Among the surgical approaches used in young patients is splenectomy, ligature of the left gastric vein and autologous implantation of spleen tissue

\footnotetext{
${ }^{+}$Corresponding author. Fax: +55-981-3342.0830. E-mail: carlosbrandt@bol.com.br

Received 14 May 2001

Accepted 25 July 2001
}

in a pouch of the major omentum (Brandt et al. 1997). When bleeding recurrence occurs the patients undergo endoscopic sclerotherapy of the esophageal varicose veins (Sakai 1995, Brandt et al. 1997). This treatment results in cure of the hypersplenism, decreasing of the upper digestive bleeding bouts, improvement of the hepatic functional reserve, improvement of the somatic development and increment of the bone mineral content (Brandt et al. 1995a, b, 1997, 1999).

The spleen tissue autoimplantation in the major omentum, original in the surgical treatment of the surgical form of schistosomiasis mansoni, has produced a significant decrease of the mortality rate due to overwhelming postsplenectomy infection (OPSI) in children with this disease. Historical mortality rate for children with this condition had been $30 \%$ to $40 \%$ and nowadays is $3.1 \%$. In the past ten years there has been no patient with OPSI in the Department of Pediatric Surgery, Federal University of Pernambuco, Brazil (Brandt et al. 1997, 1995a, b, 1997, 1999).

In the follow up of the surgical patients who had previous medical treatment with oxamniquine it has been observed, in our series, that these pa- 
tients maintain high levels of eosinophil cells and immunoglobulins $\mathrm{G}$ and $\mathrm{M}$, even among patients who had negative search, in stool, for Schistosoma mansoni. On the other hand, it has been reported the quantitative oogram $-S$. mansoni egg search and quantification in the submucosa - is more efficient in controlling the results of the medical treatment (Cunha \& Carvalho 1966, Neves 1976, Cunha \& Ferrari 1991, Vallada 1998).

The aims of this investigation were: (1) to examine the presence of residual parasite burden after medical and surgical treatment on adolescents with surgical schistosomiasis mansoni and (2) to assess the effect on the hepatic functional reserve in patients with and without residual infection.

\section{MATERIALS AND METHODS}

Patients - It was selected, at random, 29 out of 63 patients suffering from hepatosplenic schistosomiasis mansoni who had undergone medical and surgical treatments in the past ten years, cared for at the Department of Pediatric Surgery, University Hospital (Hospital das Clínicas), Federal University of Pernambuco, Recife, Brazil. These patients have received a single dose $(20 \mathrm{mg} / \mathrm{kg})$ of oxamniquine and after 30 days they underwent splenectomy, ligature of the left gastric vein and autoimplantation of spleen tissue into an omental pouch of the greater omentum. Symmers' fibrosis was confirmed in wedge liver biopsy, done in all patients.

Submucosal rectal biopsy was done under sedation. The tissue was sent for non staining microscopy examination following the steps of the oogram quantification technique (Cunha 1963, Cançado et al. 1965, Cunha \& Ferrari 1991, Vallada 1998). The S. mansoni egg search and quantification were done in the submucosa. The eggs were classified as viable (matures and non matures) and non viable.

Routine Kato-Katz was done in all patients.

The hepatic functional reserve was estimated using the parameters of the Child-Pugh classification.

Statistical analysis and ethical considerations: The chi square $\left(\chi^{2}\right)$ was used for measuring the difference among quality frequencies. $p<0.05$ was used to reject the null hypothesis. The hospital ethical committee approved this study.

\section{RESULTS}

In 20 patients the submucosal egg search was negative, however, it was positive in 9 patients. From these positive oograms, viable eggs (all mature) was seen in 6 patients, and in 3 the eggs were non viable.

The hepatic functional reserve in the patients without infection was as follows: 17 were Child-
Pugh A and 3 Child-Pugh B. In the patients who were still infected 6 were Child-Pugh A and 3 ChildPugh B. The $\chi^{2}$ analysis of the hepatic functional reserve showed $\chi^{2}=3.19-\mathrm{p}=0.07$.

As regard to the Kato-Katz investigation 6 were positive and viable eggs account for 4 patients. There was no statistical difference between the quantitative oogram and the Kato-Katz results.

\section{DISCUSSION}

It is still subject of discussion and controversy the ideal way of detecting active $S$. mansoni infection, specially after medical treatment. The KatoKatz stool investigation has been used more frequently, however, as it happens in this investigation it is less accurate than the quantitative oogram (Cunha 1963, Cançado et al. 1965, Cunha \& Carvalho 1966, Neves 1976, Rabello 1997, Vallada 1998).

Other way of measuring the efficacy of medical treatment is looking for $S$. mansoni eggs in the histology of wedge liver biopsy taken at the surgical procedure time. Domingues (1998), for example, has shown, in $22.5 \%$ of the adult patients, the presence of granuloma with portal inflamatory activity, indicating active disease. These patients had received medical treatment prior to surgery (Domingues 1998). This result represents no statistical difference from the oogram investigation in the present study $-20.7 \%$ with viable eggs and $10.3 \%$ with non viable eggs.

It has been reported strains of $S$. mansoni resistant to oxamniquine (Coelho et al. 1997). On the other hand, the dose of this drug has varied from treatment to treatment. Cunha (1997) has reported a residual parasite burden of $61.7 \%$ in the patients when a single dose of $15 \mathrm{mg}$ to $18 \mathrm{~g} / \mathrm{kg}$ was used. This result is worse than the result of this investigation. It is likely that a more ideal dose of oxamniquine may reduce the residual parasite burden.

Other relevant fact is that the treated patients go back to their usual habitat with $S$. mansoni infested rivers and they may become re-infected. Domingues (1998), for example, showed that 7 out of 14 patients previously treated with oxamniquine and living in the same endemic habitat presented with active disease in their wedge liver biopsies which were taken at operation time (Domingues 1998).

Traditionally, the seniors surgeons with great experience in the treatment of the surgical form of $S$. mansoni disease do not take into account the residual parasite burden as a parameter of influencing the overall end result of the treatment of this condition (Kelner et al. 1982, Kelner 1992).

Although not reaching statistical significance, residual infection or re-infection in the post treatment period could have affected the distribution of 
the hepatic functional reserve of the patients from this series, as it can be observed that there was a trend for a decrease of this parameter in patients with residual active infection.

We have already demonstrated that there is an association between $S$. mansoni positive oogram and the highest serum levels of immunoglobulin $\mathrm{G}$ (IgG) (Brandt et al. 1998). Furthermore, these high serum levels of IgG may be associated to the high B lymphocyte cell counts in these patients (Brandt et al. 1993). Based on these observations we should recommend rectal biopsy and submucosal search for $S$. mansoni eggs in patients who maintain high levels of IgG after medical treatment. In our institution we are giving a second treatment for the patients with active eggs in the quantitative oogram.

\section{REFERENCES}

Amaral RS, Porto MAS 1994. Evolução e situação atual do controle da esquistossomose no Brasil. Rev Soc Bras Med Trop 27: 73-90.

Barbosa CS, da Silva CB, Barbosa FS 1996. Esquistossomose: reprodução e expansão da endemia no Estado de Pernambuco no Brasil. Rev Saúde Pública 30: 609-616.

Barbosa FS, Barbosa CS, Gonçalves JF, Albuquerque Y 1997. Urban schistosomiasis in Itamaracá island, Pernambuco, Brazil: epidemiological and anthropological factors involved in the recent endemic process. In Simpósio Internacional sobre Esquistossomose 6: p. 190.

Barreto VST, Domingues ALC 1996. Doença hepática na esquistossomose. In J Coelho, Aparelho Digestivo. Clínica e Cirurgia, MEDSI - Editora Médica e Científica Ltda, Rio de Janeiro, p. 840-849.

Brandt CT, Tavares DJS 1992. Esquistossomose mansônica na forma hepatoesplênica em crianças: análise seqüencial das imunoglobulinas $\mathrm{G}, \mathrm{A}$ e M dos componentes 3 e 4 do sistema complemento antes e pós tratamento clínico. An Fac Med Univ Fed Pernamb 37: 23-26.

Brandt CT, Maciel DT, Azevedo AS 1995a. Esquistossomose mansônica em crianças: desenvol-vimento pondo-estatural após tratamento cirúrgico. An Fac Med Univ Fed Pernamb 43: 56-60.

Brandt CT, Maciel DT, Caneca OF, Alexandre F, Júnior VGA, Cordeiro F 1995b. Hipertensão portal esquistossomótica na criança: Avaliação crítica. An Fac Med Univ Fed Pernamb 40: 106-110.

Brandt CT, Moraes Filho JL, Maciel DT, Miranda P 1993. Esquistossomose hepatoesplênica na criança caracterização linfocitária no sangue periférico. An Fac Med Univ Fed Pernamb 38: 6-8.

Brandt CT, Sá HP, Frei Caneca AO, Santana JV, Miranda P, Carvalheira R 1998. Esquistossomose mansônica hepatoesplênica em adolescentes: carga parasitária após tratamento clínico cirúrgico. An Fac Med Univ Fed Pernamb 43: 123-126.

Brandt CT, Souza AMG, Braga MVM, Melo KLR, Almeida F 1999. Bone mineral density in children and adolescents with hepatosplenic mansoni schis- tosomiasis and esophageal varices who underwent splenectomy and ligature of the left gastric vein. Acta Cir Bras 19.

Brandt CT, Tavares DJS, Frei Caneca AO 1997. Splenectomy associated with ligature of the left gastric vein in children with surgical schistosomiasis: analysis of the hepatic functional reserve. Acta Cir Bras 12: $150-153$.

Cançado JR, Cunha AS, Carvalho DG, Cambraia JNS 1965. Evaluation of the treatment of human schistosoma mansoni by the quantitative oogram technique. Bull WHO 33: 557-566.

Coelho PM, Lima e Silva FC, Machado JAN 1997. Resistence to oxamniquine of a Schistosoma mansoni strain isolated from patient submited to repeated treatments. Rev Inst Med Trop 39: 101-106.

Cunha AS 1963. O Método do Oograma em Ensaios Terapêuticos Clínicos na Esquistossomose Mansoni. Thesis, Universidade Federal de Minas Gerais, Belo Horizonte, p. 120.

Cunha AS 1982. A avaliação terapêutica da oxamniquine na esquistossomose mansoni humana pelo método do oograma por biópsia de mucosa retal. Rev Inst Med Trop 24: 88-94.

Cunha AS 1986. Double-blind therapeutical evaluation based on the quantitative oogram technique, comparing praziquantel and oxamniquine in human schistosomiasis mansoni. Rev Inst Med Trop 28: 337-351.

Cunha AS 1997. Therapeutical evaluation of different dose regimens of praziquantel in schistosomiasis mansoni, based on the quantitative oogram technique. Rev Inst Med Trop 29: 295-304.

Cunha AS, Carvalho DG 1966. Estudo do método do oograma quantitativo na esquistossomose mansoni. Rev Inst Med Trop 8: 113-121.

Cunha AS, Ferrari MA 1991. Tratamento específico e avaliação da terapêutica. In LP Castro, PRS Rocha, AS Cunha (eds), Tópicos em gastroenterologia. Gastroenterologia Tropical, p. 65-88.

Domingues ALC 1998. Ultra-sonografia na Esquistossomose Mansônica Hepatoesplênica: Avaliação da Intensidade da Fibrose Periportal e da Hipertensão Porta, PhD Thesis, Universidade Federal de Pernambuco, Recife, p. 99.

Kelner S 1992. Critical evaluation of surgical treatment of schistosomotic portal hypertension. Mem Inst Oswaldo Cruz 87 (Suppl. IV): 357-368.

Kelner S, Ferreira PR, Dantas S 1982. Ligadura de varizes esôfago-gástricas na hipertensão portal esquistossomótica: avaliação de 25 anos. Rev Col Bras Cir 9: 140-146.

Neves DP 1976. Schistosoma mansoni. Parasitol Humana 20: 146.

Rabello A 1997. Diagnosing schistosomiasis. Mem Inst Oswaldo Cruz 92: 669-676.

Sakai P 1995. Late results of endoscopic scleroterapy of bleeding esofageal varices in patients with hepatic cirrhosis and schistosomiasis. Arq Bras Cir Dig 10: 17-21.

Vallada EP 1998. Parasitologia - Identificação dos helmintos. In Manual de Exames de Fezes. Coprologia e Parasitologia, Atheneu Rio, Rio de Janeiro, p. 167172. 
116 Surgical Hepatosplenic in Adolescents - Carlos Teixeira Brandt et al. 